Available online at: https://journals.researchsynergypress.com/index.php/ijtaese

International Journal of Theory and Application in Elementary and Secondary School Education

(IJTAESE)

ISSN 2684-7167 (online)

Volume X Number X(Year): 22-38

\title{
Psychological Stress among Higher Secondary School Students during Covid Era in relation to Gender, Caste, and Locality
}

\author{
Dr. Venkateswar Meher ${ }^{1}$ \& Laxmi Meher ${ }^{2}$ \\ ${ }^{1}$ Gangadhar Meher University, Sambalpur-768004, Odisha, India \\ ${ }^{2}$ Maharaja Sayajirao University of Baroda, Varodara-390002, Gujrat, India
}

\begin{abstract}
In the present research, we have taken an attempt to study stress levels among higher secondary school students during the COVID-19 period. This research aimed at studying the psychological stress level among higher secondary students during the COVID pandemic and the variations in the psychological stress among students in terms of gender, caste, locality. It also investigated the effect of gender, caste and locality, and their interaction on the stress of higher secondary school students. The descriptive survey method was used in this study. Approximately 151 students as samples were taken for the study. The sample was delimited to higher secondary students Bargarh and Sambalpur districts of Odisha. A standardized stress scale was used to collect data. The data were collected through online mode using google form as the study was conducted in the COVID era. The obtained data were analyzed through descriptive and inferential statistical tests like percentages, t-test, and ANOVA. The findings of the study revealed that $68 \%$ of students experienced moderate levels of stress, $17 \%$ of students experienced high levels of stress, and $15 \%$ of students experienced a low level of stress. The results of the t-test indicated no significant variations in the psychological stress of secondary school students with reference to their gender, caste, and locality. The results of ANOVA revealed no significant interaction influence among gender, caste, and locality on the psychological stress of higher secondary school students. As the study was conducted in the COVID era, and demographic variables like gender, caste, and streams of education were taken altogether, so this represents the novelty of the work.
\end{abstract}

Keywords: Psychological Stress; Higher Secondary School Students; COVID Era; Gender; Caste; Streams of Education

This is an open-access article under the CC-BY-NC license.

\section{INTRODUCTION}

Stress is a universal phenomenon. Stress is a situation where a person feels threatened and challenged. Stress is also associated with depression, anxiety, hopelessness, maladjustment. Stress can be caused by many factors like emotional, family, social, work, decision, communication, phobia, physical, disease, environmental. These all are stressors that can be caused stress in an individual. Many people believe that stress is a psychological condition and it discomforts a person physically, mentally, and socially. Stress can be defined as any type of change that causes physical, emotional, or psychological strain.

Corresponding author

Dr.Venkateswar Meher, venkatesmeher90@gmail.com; Laxmi Meher, kiranmeher256@gmail.com

DOI: https://doi.org/10.31098/ijtaese.v3i2.540

Research Synergy Foundation 
International Journal of Theory and Application in Elementary and Secondary School Education (IJTAESE), Vol. 3 (2), 22-38

Psychological Stress among Higher Secondary School Students during Covid Era in relation to Gender,

Caste, and Locality

Dr. Venkateswar Meher \& Laxmi Meher

Stress is the pattern of responses an organism makes to a situation or event that disturbs the equilibrium and exceeds a person's ability to cope. Stress can be of many types, like psychological stress, environmental stress, and social stress. The psychological stresses are those which generated on an individual mind by himself, like frustration, conflicts, internal pressure (expectation, achieving goal stress), and so on. Environmental stresses are all the aspects of our surroundings that are often unavoidable, such as air pollution, noise, heat, cold, etc. The social stresses come externally, which deals with the interaction with other people, family problems, etc.

Every human being on the globe experience stresses more or less. So, far as the present scenario is concerned, COVID-19 is becoming more dangerous for human life; therefore, Govt. of India and my other countries have imposed lockdown throughout the country. Particularly, the second wave in India has wreaked havoc with a massive surge in active case-loads and fatalities across the country. Following the outbreak of the deadly virus, every individual has gone into a state of inertia. Almost all the people of India are experiencing fear and stress in the context of the COVID-19 pandemic, which has changed the lifestyles of individuals. The virus has influenced people socially, emotionally, educationally, physically, and mentally. So far as the educational influence is concerned, the students of elementary and secondary education are suffering a lot due to the pandemic. The adolescence stage is a critical link between childhood and adulthood, which is highly characterized by significant physical, psychological, and social transitions. The higher secondary school students make major decisions regarding higher studies and careers in their life. This is a critical and very stressful period for them. They have the problem like interacting with the peer group, academic expectations, social dogmas, and many challenging situations, used to be faced by them. And these all have a bad effect on students' behavior which ultimately affects their studies. These are very serious problems to take into consideration because they may have affected their learning and memory for a lifetime. So, far as the present condition is concerned, the lifestyles of the students are now concerned with the online platform only, as there are lockdowns and shutdowns in maximum parts of the country. Due to this, the education of elementary and secondary school students is influenced to a great extent. Most truly speaking, India is a village-dominated country, so the students of village areas face more difficulties due to the online classes. Therefore, in the present study, an attempt has been taken to investigate the psychological stress of the higher secondary school students belonging to the urban and rural areas of Sambalpur and Bargarh district of Odisha.

\section{Psychological Stress Theory of Lazarus (1991)}

The stress theory of Lazarus has been gone through various modifications and revisions. The latest version of it regarded 'stress as a relationship between environment and individual, for the significance of individual well-being. Here two concepts have been discussed under psychological stress theory, i.e., cognitive appraisal and coping. The individual appraisal deals with the environment for its wellbeing, and in coping, the individual tries to manage specific demands. In the emotion theory, Lazarus (1991) described the stress theory by distinguishing it into two basic forms of appraisal, Primary Appraisal and Secondary Appraisal. Whereas primary appraisal consisted of three components;

(1) Goal Relevance- which extent individual care about the issues he encounters.

(2) Goal Congruence- in accordance with a personal goal to which extent an episode can proceed.

(3) Ego- Involvement types- moral values, self-esteem, ego-ideal. 
International Journal of Theory and Application in Elementary and Secondary School Education (IJTAESE), Vol. 3 (2), 22-38

Psychological Stress among Higher Secondary School Students during Covid Era in relation to Gender, Caste, and Locality

Dr. Venkateswar Meher \& Laxmi Meher

There are also three components of secondary appraisal,

(1) Blame or Credit- an individual's appraisal for an event.

(2) Coping Potential- evaluation by a person of certain cognitive operations that positively influence individual personality.

(3) Future Expectations- appraisal of the further course of an encounter.

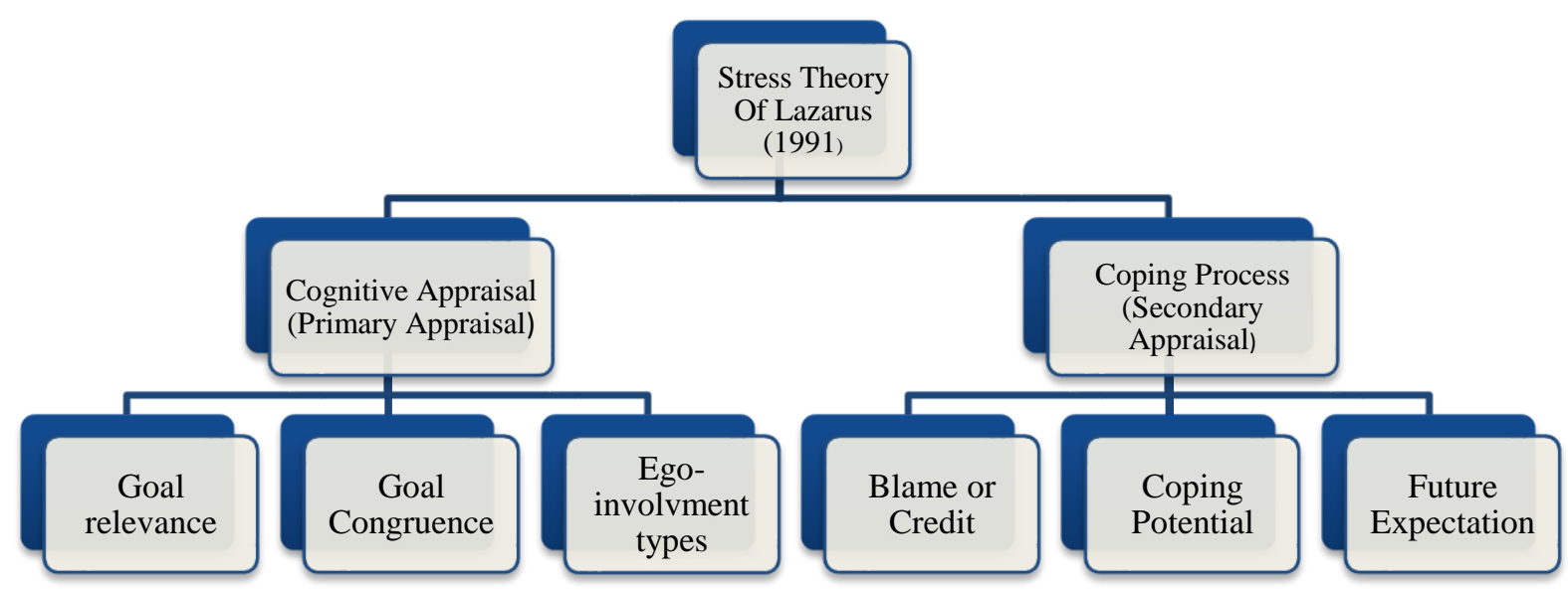

Figure. 1 Component of stress (Source: Lazarus, 1991)

These primary and secondary appraisals lead to different kinds of stresses. There are three psychological stresses based on this.

(1) Harm- It refers to the psychological loss or damage that already happened in the past.

(2) Threat- It is the anticipation of harm.

(3) Challenge- It is the result of demand due to the confidence of the person.

\section{Stress Theory of Response, Stimulus, and Transaction}

In understanding stress, in Strangor \& Walinga (2014), Stress can be viewed as three models; a response, a stimulus, and a transaction.

a) Stress as a Response- In Hans Selye (1956), stress is described as a physiological response pattern, and it has been included under his GAS (General Adaptation Syndrome) model. In this model, stress is considered as a dependent variable, and it includes three concepts. (1) Stress is a defensive mechanism. (2) Stress follows the three stages of alarm, resistance, and exhaustion. (3) Severe stress can result in adaptive diseases, and it may also lead to death.

b) Stress as a Stimulus- In the year 1960, stress as a stimulus was introduced. It is viewed that stress is a significant life event or change that demands a response, adjustment, or adaptation. Stress as a stimulus theory assumes to be; change is inherently stressful, life events demand the same levels of adjustment across the population, there is a common limit to it beyond which illness may result. But this theory ignored some important variables like personality, environment, life experiences. 
International Journal of Theory and Application in Elementary and Secondary School Education (IJTAESE), Vol. 3 (2), 22-38

Psychological Stress among Higher Secondary School Students during Covid Era in relation to Gender,

Caste, and Locality

Dr. Venkateswar Meher \& Laxmi Meher

c) Stress as a Transaction- Transactional Theory of Stress and Coping (TTSC) was developed by Richard Lazarus (Lazarus \& Folkman, 1984). This theory presents stress as a transaction between a person and his environment. It includes multiple systems; physiological, psychological, neurological, cognitive, affective. The nature of stress is described by the different types of stressors by various researchers. Different types of stressors are situation, event, condition, and cue. These stressors are divided into various categories based on tone, control, impact, duration, and predictability.

\section{LITERATURE REVIEW}

The study on academic stress and mental health of Indian school students and the association between various psychosocial factors and academic stress, which revealed that $63.5 \%$ of total students reported stress due to academic pressure, and there were no significant differences across age, gender, and grade (Dev et al., 2015). Researchers examined cognitive, physiological, and social influences sources of stress by those revies. This study revealed that stress among students varied from $15 \%$ to $45 \%$. Factors like peer competition, excessive assignments, frequent examinations, poor social relationships, poor time management skills were the main reason for the academic stress of students. The management techniques like life skills training, yoga, mindfulness meditation, biofeedback, and the like, have been suggested by different studies (Reddy et al. 2017).

The study on academic stress among higher secondary school students examined the level of academic stress. The result of the study revealed that there was a highly significant difference between the academic stress of male and female participants students of higher secondary school. And there was no significant difference found among the arts, science, and commerce stream students; there was no significant difference between academic stress of govt aided and selffinanced school and rural and urban area school students (Sagar \& Singh, 2017). The study on sources of stress among youth revealed interpersonal relations, academic problems, career exploration as important sources. Such stress causes physical, psychological, and behavioral problems. This study, at last, suggested that more emphasis should be given to the developmental stage of the child into adolescents. The positive environment, outdoor activities, hostile learning environment, etc. can help remove the stress of youth (Bhargava \& Trivedi, 2018). The study on causes of stressor, academic stress, and coping strategies concluded that the causes of academic stress during schooling are inability to cope with study, lack of competence, family-related problem, peer pressure. The negative attitude, high expectation, and the high aspiration of students also cause stress in them because they suffer from various mental disorders and depression. They have also said that the lack of support from both teachers and parents leads to stress among students. Therefore, there should be a social support group for managing the stress of students (Chandan \& Shivappa, 2020). The study on academic stress and physical activity in adolescents indicated that adolescents reporting academic stress have less physical activity during recesses or after school than adolescents without academic stress. Differences in the overall physical activity between boys and girls with and without academic stress were not statistically significant for any of the physical activity characteristics (Fromel, 2020). The study on academic stress and adolescent distress on 12th standard students in mixed-method revealed that there were the majority of students reported very high stress. And also, it is said that different group of students experiences distress in different ways (the academic track, gender, and school types). It was concluded that academic stress and adolescent distress is significant problem for which interventions are needed (Rao, 2020).

Based on the theoretical framework of the study, some sorts of related literature were collected from different sources related to the stress of students. The collected literature revealed that some of the studies were conducted in India i.e., Dash, 1994; Nayak, 1996; Kaur, 2011; Raghavan, 2013; Jose et al., 2014; Sandhu, 2014; Jain, 2017; Afreen, 2018; Rana et al., 2020. And 
International Journal of Theory and Application in Elementary and Secondary School Education (IJTAESE), Vol. 3 (2), 22-38

Psychological Stress among Higher Secondary School Students during Covid Era in relation to Gender,

Caste, and Locality

Dr. Venkateswar Meher \& Laxmi Meher

some of the studies were done abroad, i.e., Martin et al., 2006; Suldo et al., 2009; Yikealo et al., 2018; Pascoe et al., 2019 and Tuncay et al., 2020. Among these, some studies were on stress which was related to the academic performances of students (Dash, 1994; Kaur, 2011; Raghavan, 2013; Jose et al., 2014 and Afreen, 2018). In an experimental study, it was found that females showed higher academic self-concept, higher stress, and comparable academic performance to males (Dash, 1994). Through a descriptive survey method, it was found that academic stress did not have any significant direct association with personality, emotional stress in adolescents affects the personality or viceversa, personality is not affected by social stress (Kaur, 2011).

The reason for the stress of students may be the size of the family, educational qualification of the father, and the perception of physiological, cognitive and behavioral, and social before intervention and intervention reduced the stress of adolescent students and improved the academic performance (Raghavan, 2013). There existing correlation between academic stress and self-esteem though its low found out in a study (Jose et al. 2014). A study conducted through an online survey showed, stress affects students mentally, physically, and emotionally and they face anxiety which later leads to go in depression, and at last, it affects their academic performance (Afreen et al., 2018). Few studies based on measuring the level of stress of students by the researchers (Martin et al., 2006; Yikealo et al., 2018 and Tuncay et al., 2020). Their findings were different from each other as they have taken the studies based on different criteria. One of the studies showed that students who were interested in the classroom reported higher levels of pressure from school (Martin et al., 2006). One finding revealed that most academic and environmental stress contributed to the higher stress level of students. On the other hand, social, psychological, and physiological stress reported a low level, and both the gender experienced moderate levels of stress (Yikealo et al., 2018).

Male students have more stress than females; this is due to "lack of confidence in being good students" and "exams after graduation" tension of male students, female students had higher stress levels of "frequency of visiting parents" and "sleeping routine" than male students (Tuncay et al., 2020). Some studies were related to the reaction to deal with the stress and coping strategies of stress (Nayak, 1996; Sandhu, 2014; Jain, 2017 and Pascoe et al., 2019). And their findings revealed that all most all children, irrespective of area, age, and sex, reported using certain coping actions naturally, like acceptance and relaxation coping behavior (Nayak, 1996). In adolescents with sleep disturbances, Global Pittsburg scores were found to be significantly and negatively related to Inadequate Study Facilities, Confrontive Coping, Distancing, and Seeking Social Support (Sandhu, 2014). Psychological Capital (Psy-Cap) combination of four positive constructs, namely; Hope, Selfefficacy, Resilience, and Optimism, is a positive resource which able to prevent stress, turnover, anxiety, and depression. The people with high Psy-Cap experienced a lesser amount of stress (Jain, 2017). One study revealed that the academic-related stress experienced by students impacts their mental and physical health and leads to a range of academic problems.

Therefore, providing opportunities to improve young people's academic stress-related coping abilities during this highly stressful, crucial period of development should be an important target (Pascoe et al., 2019). Two important research studies investigated sources of stress and its effect on students (Suldo et al., 2009, Rana et al., 2019). As discussed in one of the results of the studies after a longitudinal investigation that the primary source of stress experienced by college preparatory program was related to academic requirements; in contrast, students in the general education program indicated a higher level of stressors associated with parent-child relation, academic struggles, conflict within the family, and peer relation, as well as role transitions and societal problems (Suldo et al. 2009). Another study stated that stress arises due to the demands of persons and that person's inability to meet those demands, main sources of stress studies, work, career and future, family, economic problems and lack of facilities, social, health and physical matter, and self-image (Rana et al., 2019). 


\section{Conceptual Framework}

Based on the findings of related literature, the present study was taken into accounts in relation to the research gaps. In the present study, an attempt was taken to investigate the psychological stress level among higher secondary school students. The study also aims at studying the influence of interactions among gender, caste, and locality on the psychological stress of higher secondary school students. Based on the purpose of the study, the conceptual framework of the study was made, which is presented below.

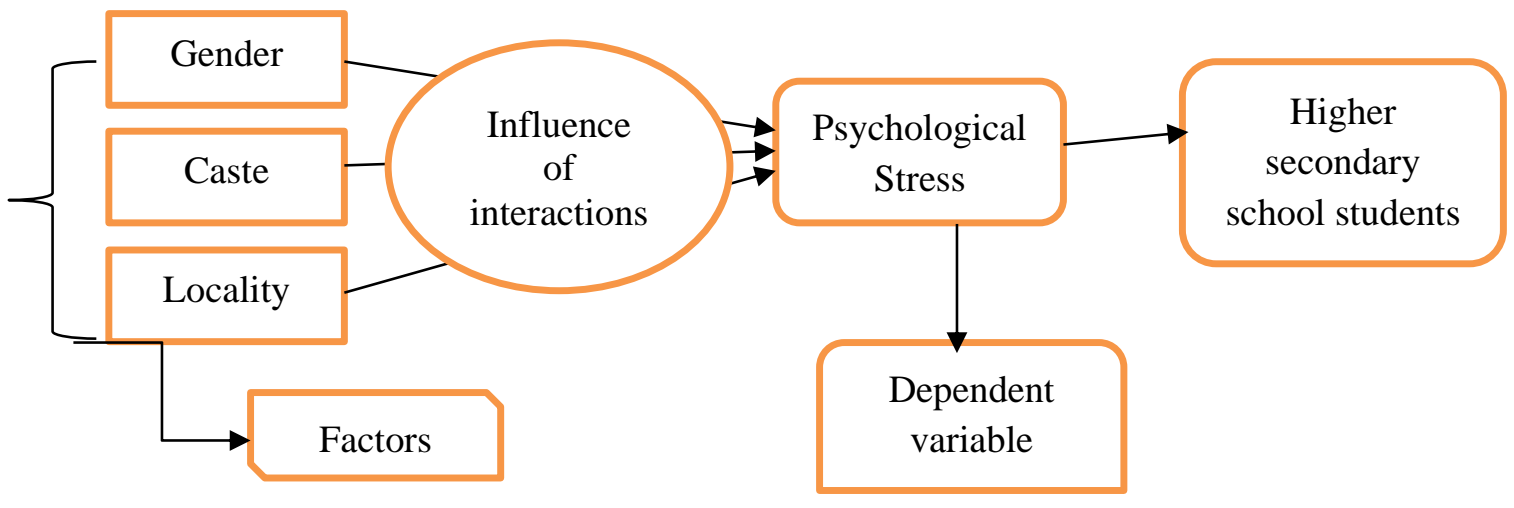

Figure. 2 Conceptual frameworks of the study

\section{Rationale of the Study}

From the given reviews of related literature, it can be noticed that many studies have been conducted that are related to the stress of students, mostly of adolescence stage students. Also, it is described in the Piaget developmental stage that adolescence is a very crucial period of children's lives, where they feel so much pressure, and they are moving towards adulthood. It is the age between 16 years to 18 years of students which falls under the adolescent's age. It has been proved in many pieces of research that adolescence is a period of full stress, strain, pressure, storm, and strife. And from these reviews described above, we come to know that students face challenges in their daily life and when they are unable to deal with those challenges, then they have the problem like insomnia, anxiety, headaches, nervousness, and all. These all ultimately lead students to be under stress. And this stress affects individuals emotionally, physiologically, and behaviorally. Covid-19 may be considered as a new area of research, recently adding in the various studies of social science research. It is a stressful period for many, a period where people face so many new problems that they have never experienced before. The most affected field in this period is the educational field, as schools and colleges remain closed for a very long time. This may have an impact on students on various matter. That is the intention of the study to find out the psychological stress level among higher secondary school students. The study also attempts to examine the role of gender, locality, and caste on the psychological stress of the students. The study was undertaken in the district of Bargarh and Sambalpur of Odisha because these two states play a vital role in providing education to the students of western Odisha. Based on the rationale of the study, the following research questions have emerged.

1. What is the level of psychological stress among higher secondary students during the COVID era? 
International Journal of Theory and Application in Elementary and Secondary School Education (IJTAESE), Vol. 3 (2), 22-38

Psychological Stress among Higher Secondary School Students during Covid Era in relation to Gender, Caste, and Locality

Dr. Venkateswar Meher \& Laxmi Meher

2. Is there any variation in the psychological stress level of higher secondary school students in terms of their gender, caste, and locality?

3. What is the influence of gender, caste, locality, and their interactions on psychological stress on the study of higher secondary students?

\section{Objectives of the Study}

1. To study the psychological stress level among higher secondary students during the COVID era.

2. To study variations in the psychological stress level among secondary school students in terms of their gender, caste, and locality.

3. To study the influence of gender, caste, locality, and their interactions on psychological stress of higher secondary students.

\section{Hypotheses of the Study}

1. There exist no significant variations in the psychological stress level of secondary school students in terms of their gender, caste, and locality.

2. There exists no significant influence of gender, locality, and caste and their interactions on psychological stress on the study of higher secondary students.

\section{Delimitations of the Study}

- The present study was delimited to higher secondary students of Sambalpur and Bargarh district of Odisha.

- The present study was delimited to the psychological stress of higher secondary school students.

- The stress was operationally delimited to pressure, physical stress, anxiety, and frustration of the higher secondary school students.

\section{METHODOLOGY}

\section{Method \& Design}

Since this was a study during COVID-19, and the primary purpose was to study the stress among higher secondary school students in the COVID era, it was convenient to use the descriptive survey method. Along with that, to study the influence of interactions among gender, locality, and caste on psychological stress, $2 * 3 * 2$ factorial design was also used.

\section{Population and Sample}

All the students of the higher secondary stage of Odisha were the population in the study. Near about 151 higher secondary school students were selected as the sample of the study purposively as data was collected through Google Form in online mode. Conveniently, the higher secondary school students of Bargarh and Sambalpur locality were taken into account.

\section{Tools and Techniques}

In order to collect data, a stress scale developed and validated by Dr. Vijaya Lakshmi and Dr. Shruti Narain was used. The stress scale consisted of 40 items having four important components, i.e., pressure (14 items), physical stress (04 items), anxiety (13 items), and frustration (09 items). The scale included both negative (Item No. 21,35) and positive items. The items of the scale were in English language, so whenever required, proper assistance was given to the students during its 
International Journal of Theory and Application in Elementary and Secondary School Education (IJTAESE), Vol. 3 (2), 22-38

Psychological Stress among Higher Secondary School Students during Covid Era in relation to Gender,

Caste, and Locality

Dr. Venkateswar Meher \& Laxmi Meher

implementation. The test-retest reliability of the scale was 0.82 , and concurrent validity with Singh's Personal Stress Source Inventory was 0.72 . The scale was meant for boys and girls in the age range of 12 to 24 years of students. The prescribed standard scoring manual was followed in the present study for scoring.

\section{Data Collection}

To collect data in the pandemic situation of covid-19, an online data collection method was used through Google Form. There was a link created from the google form website, where all the items of the standardized stress scale were mentioned and sent to the students through WhatsApp and Email. Students were requested to fill up the google form through the link and submit it. The obtained data were kept confidential and used for this research purpose only.

\section{Statistical Techniques}

To analyze obtained data, both descriptive and inferential statistical techniques were used in the present study. The nature of the distribution of the obtained data was tested, which revealed normal distribution. To study the level of stress, norms of the Stress Scale were followed, and the percentage technique was used. To analyze the variations in psychological stress t-test was used, and ANOVA statistical technique was used to study the influence of interactions.

\section{ANALYSIS AND INTERPRETATION OF DATA}

The obtained data were analyzed by using both descriptive and inferential statistical techniques based on the objectives. The data were analyzed and interpreted below.

\section{a) Analysis of psychological stress level}

One of the objectives of the study was to find out the level of psychological stress among higher secondary school students. For this, the norms of the Stress Scale were followed. As per the norms, a stress score between 0-13 indicated low stress, a score between 14-24 indicated moderate score, and a score of 25 and above indicated high stress. Accordingly, the raw data of the stress scale was arranged, and calculation was done. The obtained data regarding the level of stress among higher secondary school students are depicted in the following table and figure.

Table. 1 Level and percentage of stress among students

\begin{tabular}{|l|c|c|c|c|}
\hline $\begin{array}{l}\text { Sl. } \\
\text { No. }\end{array}$ & Stress level & Norms & $\begin{array}{l}\text { Number of } \\
\text { students }\end{array}$ & Percentage \\
\hline 1 & Low Stress & 0 to 13 & 22 & $14.57 \%$ \\
\hline 2 & Moderate Stress & 14 to 24 & 103 & $68.21 \%$ \\
\hline 3 & High Stress & $25+$ & 26 & $17.22 \%$ \\
\hline
\end{tabular}

The data of the above table reveals that near about 22 students of the total sample had low stress, 103 students showed moderate stress, and 26 students had high stress in the COVID era. The data makes it clear that most of the students were having moderate psychological stress. 


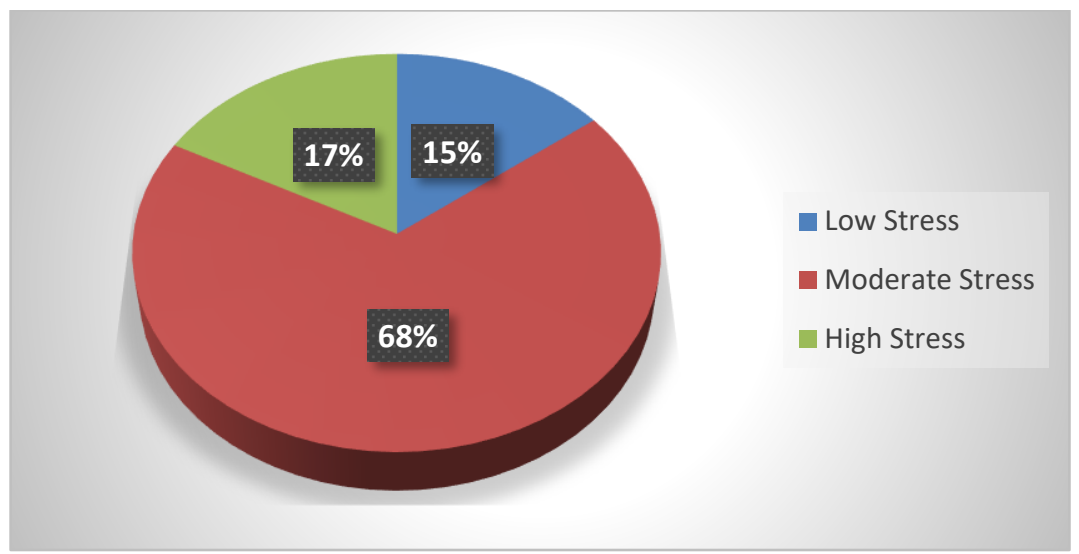

Figure. 3 Percentage of stress level among students

The above figure reveals the percentage of psychological stress found among higher secondary school students in the COVID era. The data reveals that about 68\% samples of the study had moderate stress; next to this, near about $17 \%$ of students were having high stress, and $15 \%$ of students had low stress. So, there is a need to implement stress management strategies for the benefit of higher secondary school students to minimize their stress.

\section{b) Analysis of variations in psychological stress}

i) Gender-wise variations: One of the objectives of the study was to find out the variations in the psychological stress among higher secondary school students in terms of their gender. As per this objective, gender had two levels, namely boys and girls, so the data was analyzed with the help of a t-test using SPSS-23, and the results are given below.

Table. 2 Gender wise N, mean, SD, df, and t-value of stress

\begin{tabular}{|cccccccc|}
\hline Gender & $\mathbf{N}$ & Mean & SD & Df & t-value & Sig. & Remark \\
\cline { 1 - 5 } Boys & 48 & 19.10 & 6.26 & 149 & 0.86 & .932 & ns \\
\cline { 1 - 4 } Girls & 103 & 19.00 & 7.23 & & & & \\
\hline
\end{tabular}

ns: not significant at 0.05 level

From the above table, it is evident that the t-value of psychological stress is 0.86 , which is not significant at 0.05 level with $\mathrm{df}=149$. It shows that the mean scores of psychological stress among higher secondary school students did not differ significantly in terms of their gender. Thus, the null hypothesis that there is no significant difference between the mean scores of psychological stresses of boys and girls is not rejected. It may, therefore, be said that higher secondary boys and girls were found to have psychological stress to the same extent in the COVID era.

ii) Locality-wise variations: One of the objectives of the study was to find out the variations in the psychological stress among higher secondary school students in terms of their locality. As per this objective, the locality had two levels, namely urban and rural locality, so the data was analyzed with the help of a t-test using SPSS-23, and the results are given below. 
International Journal of Theory and Application in Elementary and Secondary School Education (IJTAESE), Vol. 3 (2), 22-38

Psychological Stress among Higher Secondary School Students during Covid Era in relation to Gender,

Caste, and Locality

Dr. Venkateswar Meher \& Laxmi Meher

Table. 3 Locality wise N, mean, SD, df, and t-value of stress

\begin{tabular}{|cccccccc|}
\hline Locality & N & Mean & SD & Df & t-value & Sig. & Remark \\
\cline { 1 - 4 } Urban & 69 & 18.65 & 5.65 & & & & \\
\cline { 1 - 4 } & 82 & 19.35 & 7.84 & 149 & 0.620 & 0.536 & ns \\
\hline
\end{tabular}

ns: not significant at 0.05 level

From the above table, it is evident that the t-value of psychological stress is 0.62 , which is not significant at 0.05 level with $\mathrm{df}=149$. It shows that the mean scores of psychological stresses among higher secondary school students belonging from urban and rural areas did not differ significantly. Thus, the null hypothesis that there is no significant difference between the mean scores of psychological stress of higher secondary school students is not rejected in terms of their locality. It may, therefore, be said that higher secondary students belonging from urban and rural areas were found to have psychological stress to the same extent in the COVID era.

iii) Caste-wise variations: One of the objectives of the study was to find out the variations in the psychological stress of higher secondary school students in terms of their caste. As per this objective, there were three levels of Caste, General, Scheduled Caste (SC), and Scheduled Tribe (ST). So, the data was analyzed with the help of a t-test thrice by using SPSS-23, and the results are given below.

Table. 4 Caste wise N, mean, SD, df, and t-value of stress

\begin{tabular}{|c|c|c|c|c|c|c|c|}
\hline Groups & $\mathbf{N}$ & Mean & SD & df & t-value & Sig. & Remark \\
\hline General & 82 & 19.38 & 7.57 & 115 & 0.573 & .568 & ns \\
\hline SC & 35 & 18.54 & 6.29 & & & & \\
\hline $\mathrm{SC}$ & 35 & 18.54 & 6.29 & 67 & 0.111 & .912 & ns \\
\hline ST & 34 & 18.71 & 5.93 & & & & \\
\hline General & 82 & 19.38 & 7.57 & 114 & 0.462 & .645 & ns \\
\hline ST & 34 & 18.71 & 5.93 & & & & \\
\hline
\end{tabular}

ns: not significant at 0.05 level

From the above table, it is evident that the $\mathrm{t}$-values of psychological stress were found as $0.573,0.111$, and 0.462 for General and SC, and SC and ST, General and ST higher secondary school students respectively, which are not significant at 0.05 level with $\mathrm{df}=115,67$ and 144 respectively. It shows that the mean scores of psychological stress of higher secondary school students belonging from General, SC, and ST categories did not differ significantly. Thus, the null hypothesis that there is no significant difference among the mean scores of psychological stress of higher secondary school students belonging from the General, SC, and ST categories is not rejected. It may, therefore, 
International Journal of Theory and Application in Elementary and Secondary School Education (IJTAESE), Vol. 3 (2), 22-38

Psychological Stress among Higher Secondary School Students during Covid Era in relation to Gender,

Caste, and Locality

Dr. Venkateswar Meher \& Laxmi Meher

be said that higher secondary school students belonging to the General, SC, and ST categories were found to have psychological stress to the same extent in the COVID era.

\section{c) Analysis of the influence of interaction among gender, locality, and caste on psychological stress of higher secondary students}

One of the objectives of the study was to examine the influence of gender, caste, and locality and their interactions on the psychological stress among higher secondary school students. As per this objective, there were two levels of gender, namely boys and girls, three levels of caste, namely General, Scheduled Caste, and Scheduled Tribe, and two levels of locality, namely, urban and rural. To investigate this objective, Three-Way ANOVA or $2 * 3 * 2$ Factorial Design ANOVA was used by using SPSS-23, and the results are interpreted below.

Table. 5 Result of Three-Way ANOVA

\begin{tabular}{|c|c|c|c|c|c|c|}
\hline \multirow[b]{2}{*}{ Source } & \multicolumn{6}{|c|}{ Tests of Between-Subjects Effects } \\
\hline & $\begin{array}{l}\text { Type III Sum } \\
\text { of Squares }\end{array}$ & Df & $\begin{array}{c}\text { Mean } \\
\text { Square }\end{array}$ & $\mathbf{F}$ & Sig. & $\begin{array}{c}\text { Remark } \\
\text { s }\end{array}$ \\
\hline Corrected Model & $377.007 a$ & 11 & 34.273 & .701 & .736 & \\
\hline Intercept & 28620.765 & 1 & 28620.765 & 585.574 & .000 & \\
\hline Gender & 75.171 & 1 & 75.171 & 1.538 & .217 & ns \\
\hline Caste & 103.553 & 2 & 51.776 & 1.059 & .349 & ns \\
\hline Locality & 11.722 & 1 & 11.722 & .240 & .625 & ns \\
\hline Gender* Caste & 196.932 & 2 & 98.466 & 2.015 & .137 & ns \\
\hline Gender* Locality & 5.234 & 1 & 5.234 & .107 & .744 & ns \\
\hline Caste * Locality & 138.387 & 2 & 69.194 & 1.416 & .246 & ns \\
\hline $\begin{array}{l}\text { Gender* Caste * } \\
\text { Locality }\end{array}$ & 42.929 & 2 & 21.465 & .439 & .645 & ns \\
\hline Error & 6793.827 & 139 & 48.876 & & & \\
\hline Total & 61872.000 & 151 & & & & \\
\hline Corrected Total & 7170.834 & 150 & & & & \\
\hline a. R Squared $=.053$ & ted R Square & $-.022)$ & & & & \\
\hline
\end{tabular}

ns: not significant at 0.05 level

i) Influence of gender on psychological stress: The F-value of 1.538 for gender is not significant at 0.05 level with $\mathrm{df}=1 / 139$. It indicates that the mean scores of psychological stress of students did not differ significantly in terms of their gender. So, there was no significant influence of gender on the psychological stress of higher secondary school students. Thus, the null hypothesis that there is no significant influence of gender on the psychological stress of higher secondary school students is accepted. So, there was no significant influence of gender on the psychological stress of higher secondary school students. 
International Journal of Theory and Application in Elementary and Secondary School Education (IJTAESE), Vol. 3 (2), 22-38

Psychological Stress among Higher Secondary School Students during Covid Era in relation to Gender,

Caste, and Locality

Dr. Venkateswar Meher \& Laxmi Meher

ii) Influence of locality on psychological stress: The F-value of 0.240 for locality is not significant at 0.05 level with $\mathrm{df}=1 / 139$. It indicates that the mean scores of psychological stress of students belonging from urban and rural locality did not differ significantly. So, there was no significant influence of locality on the psychological stress of higher secondary school students. Thus, the null hypothesis that there is no significant influence of locality on psychological stress of higher secondary school students is accepted. So, there was no significant influence of locality on the psychological stress of higher secondary school students.

iii) Influence of caste on psychological stress: The F-value of 1.06 for gender is not significant at 0.05 level with $\mathrm{df}=2 / 139$. It indicates that the mean scores of psychological stress of students belonging from General, SC, and ST categories did not differ significantly. So, there was no significant influence of caste of students on psychological stress of higher secondary school students. Thus, the null hypothesis that there is no significant influence of caste on the psychological stress of higher secondary school students is accepted. So, there was no significant influence of caste on the psychological stress of higher secondary school students.

iv) Influence of interaction between gender and locality on psychological stress: The F-value of 0.107 for interaction between gender and locality is not significant at 0.05 level with $\mathrm{df}=1 / 139$. It indicates that the mean scores of higher secondary boys and girls belonging from urban and rural localities did not differ significantly. So, there was no significant influence of interaction between gender and locality on the psychological stress of higher secondary school students. Thus, the null hypothesis that there is no significant influence of interaction between gender and locality on psychological stress of higher secondary school students is accepted. So, there was no significant influence of interaction between gender and locality on the psychological stress of higher secondary school students.

v) Influence of interaction between locality and caste on psychological stress: The F-value of 1.416 for interaction between locality and caste is not significant at 0.05 level with $\mathrm{df}=2 / 139$. It indicates that the mean scores of higher secondary students belonging from the urban and rural locality and General, SC, and ST categories did not differ significantly. So, there was no significant influence of interaction between locality and caste on the psychological stress of higher secondary school students. Thus, the null hypothesis that there is no significant influence of interaction between locality and caste on psychological stress of higher secondary school students is accepted. So, there was no significant influence of interaction between gender and locality on the psychological stress of higher secondary school students.

vi) Influence of interaction between gender and caste on psychological stress: The F-value of 2.015 for interaction between gender and caste is not significant at 0.05 level with $\mathrm{df}=2 / 139$. It indicates that the mean scores of higher secondary boys and girls belonging from the General, $\mathrm{SC}$, and ST categories did not differ significantly. So, there was no significant influence of interaction between gender and caste on the psychological stress of higher secondary school students. Thus, the null hypothesis that there is no significant influence of interaction between gender and caste on psychological stress of higher secondary school students is accepted. So, there was no significant influence of interaction between gender and caste on the psychological stress of higher secondary school students. 
International Journal of Theory and Application in Elementary and Secondary School Education (IJTAESE), Vol. 3 (2), 22-38

Psychological Stress among Higher Secondary School Students during Covid Era in relation to Gender,

Caste, and Locality

Dr. Venkateswar Meher \& Laxmi Meher

vii) Influence of interaction among gender, caste, and locality on psychological stress: The Fvalue of 0.439 for interaction among gender, caste, and locality is not significant at 0.05 level with $\mathrm{df}=2 / 139$. It indicates that the mean scores of higher secondary boys and girls belonging from the urban and rural locality and General, SC, and ST categories did not differ significantly. So, there was no significant influence of interaction among gender, caste, and locality on the psychological stress of higher secondary school students. Thus, the null hypothesis that there is no significant influence of interaction among gender, caste, and locality on psychological stress of higher secondary school students is accepted. So, there was no significant influence of interaction among gender, caste, and locality on the psychological stress of higher secondary school students.

\section{FINDINGS}

- The psychological stress level among higher secondary students during the COVID period was moderate as the maximum number of students that is $68 \%$ of the total sample, showed a moderate level of stress.

- There found no significant variations between the psychological stress of boys and girls higher secondary school students.

- There found no significant variations in the psychological stress of higher secondary school students belonging from the General, Scheduled Caste, and Scheduled Tribes category.

- There found no significant variations in the psychological stress level of higher secondary school students belonging from the urban and rural locality.

- There found no significant independent influence of gender on psychological stress of higher secondary school students.

- There found no significant independent influence of locality on psychological stress of higher secondary school students.

- There found no significant independent influence of caste of students on psychological stress of higher secondary school students.

- There found no significant influence of interaction between gender and locality on the psychological stress of higher secondary school students.

- There found no significant influence of interaction between locality and caste on psychological stress of higher secondary school students.

- There found no significant influence of interaction between gender and caste on the psychological stress of higher secondary school students.

- There found no significant influence of interaction among gender, caste, and locality on the psychological stress of higher secondary school students.

\section{DISCUSSION OF THE RESULTS}

Stress is an important component investigated by different researchers of the globe before the pandemic. During the pandemic, it was the right time to measure the stress of students into consideration for their better life. The result of the study showed $17 \%$ and $15 \%$ of the sample have high stress and low stress, respectively, while $68 \%$ sample has a moderate level of stress. In the finding of the study by Yikealo et al. (2018), students experienced moderate levels of stress, and also, there was no significant difference between the male and female students. In the present study, we found out the same result as discussed in the study of Yikealo et al. (2018). But this was at college level students while we have taken higher secondary students as the sample in our studies. No 
International Journal of Theory and Application in Elementary and Secondary School Education (IJTAESE), Vol. 3 (2), 22-38

Psychological Stress among Higher Secondary School Students during Covid Era in relation to Gender,

Caste, and Locality

Dr. Venkateswar Meher \& Laxmi Meher

gender difference was also revealed in some other studies on stress (Reddy et at., 2017; Fromel et al., 2020), so these studies supported the finding of the present study. On the other hand, some studies revealed significant gender differences in terms of stress of students (Sagar \& Singh, 2017; Rao, 2020), so these findings were contradictory for the present study. Our result of the study indicated that maximum students experienced moderate levels of stress during the covid pandemic time. There was no significant difference in the stress level of students based on caste (Gen/OBC, ST \& ST), gender (Male \& Female), and locality (Urban \& Rural). But in the result of the study Tuncay et al. (2020), male students have more stress than females; this is due to "lack of confidence in being good students" and "exams after graduation" tension of male students, female students had higher stress levels of "frequency of visiting parents" and "sleeping routine" than male students. So, our finding in this regard was contradictory. So far as the results of the ANOVA were concerned, there was no significant influence of gender, locality, and caste, and their interactions on psychological stress on the study of higher secondary students. However, these findings were considered as new findings, as we took gender, caste, and locality altogether in the study, which made it clear that the psychological stress level among the higher secondary boys and girls students belonging from the urban-rural locality, General, SC, and ST category did not differ significantly. The analysis of the findings of the present study helps to draw the inference that COVID-19 was spread all over the world rapidly, about which everyone was well aware equally irrespective of caste, gender, locality, etc., so there would not be a significant difference in the stress level of students in terms of their gender, caste, and locality. However, there may be some possible reasons for the insignificant results, which may be investigated in further research studies.

\section{Implications of the Study}

It is an accepted fact that psychological stress includes depression, anxiety, the problem with cognitive functioning, and changes in behavior. In the present study, the psychological stress among higher secondary school students was examined, and the results indicated that maximum students experienced moderate level stress, and a smaller number of students experienced high and low psychological stress during the COVID era. So, this finding implies that proper measures should be taken by the parents of students for the minimization of the stress level of their children at home. Similarly, this finding also has implications for teachers that the teachers should organize online seminars and workshops on stress management for the higher secondary school students. The results of the study also indicated no significant influence of interactions among gender, caste, and locality on the psychological stress of the higher secondary school students, so the findings have implications for teachers and policymakers. Adequate measures should be taken by the stakeholders of education to reduce the psychological stress among higher secondary school students irrespective of their gender, caste, and locality.

\section{CONCLUSION}

A pandemic (COVID) which made stunned everyone, leads to different problems and difficulties in human life. Everyone got affected by this situation. Stress is an important component at this time to be considered. Stress is nothing but a discomfort situation for an individual while dealing with his environment. Stress can be environmental, social, or psychological. Among all the stages of life in adolescence stage, stress is unavoidable in which. In this period, stress at its highest, it is due to various factors, as in this period, adolescence need to make many serious decisions 
International Journal of Theory and Application in Elementary and Secondary School Education (IJTAESE), Vol. 3 (2), 22-38

Psychological Stress among Higher Secondary School Students during Covid Era in relation to Gender,

Caste, and Locality

Dr. Venkateswar Meher \& Laxmi Meher

related to life. The current study result revealed that students of adolescence experienced stress, though it is on a moderate level. There was no difference in experiencing stress between malefemale, among different castes and also between area rural or urban; as everyone experiencing stress at the same level. The study also revealed no significant influence of interactions among gender, caste, and locality on the psychological stress of students. So, it can be concluded that most of the adolescent students of Sambalpur and Bargarh district of Odisha experienced a moderate level of stress during the COVID era. The findings are generalizable for the higher secondary boys and girls school students belonging from the rural-urban locality and different categories.

\section{LIMITATION \& FURTHER RESEARCH}

The present study was limited to the psychological stress of higher secondary school students belonging from Sambalpur and Bargarh district of Odisha, India. The methodology of the study was limited to descriptive survey research following parametric statistical tests. From the findings of the present study, it can be suggested that further researches may be undertaken to correlate the psychological stress and academic performance of higher secondary school students. Further studies may also be undertaken to study the effect of other factors like family climate/home environment, peer groups, stream of education, etc., on the psychological stress of higher secondary school students. Further studies may be undertaken for the stress-coping/management techniques for the higher secondary school students. Psychological stress and other kinds of stress of secondary school students may be taken into account for further research.

\section{ACKNOWLEDGMENT}

We are thankful to the participants of the Sambalpur and Bargarh districts for their cooperation and active participation in the study.

\section{FUNDING DETAILS}

This research is the result of the financial grants given by the University Grant Commission, Bahadur Shah Zafar Marg, New Delhi-110002, India. So, we are very much thankful to the University Grant Commission (UGC), New Delhi, India, for providing Junior Research Fellowship in conducting such research-based activities.

\section{DISCLOSURE STATEMENT}

No potential conflict is reported in this study.

\section{REFERENCES}

Afreen, M. M., Priya, V. V., Gayathri, R. (2018). Effect of stress on academic performance of students in different streams. Drug Invention Today, 10((9), 1176-1780.

Bhargava, D. \& Trivedi, H (2018). A study of causes of stress and stress management among youth. International Journal of Management \& Social Sciences, 11(3). DOI: 10.21013/jmss.v11.n3.p1

Chandan, K. P. \& Shivappa R. (2020). Academic stress among higher secondary school students: an overview. International Journal of Creative Research Thought (IJCRT), 8(10).

Dash, R. (1994). Academic self-concept, stress and academic performance: A study of the scheduled caste, scheduled tribe and general Arts and Science students. Retrieved fromhttp://hdl.handle.net/10603/20979 
International Journal of Theory and Application in Elementary and Secondary School Education (IJTAESE), Vol. 3 (2), 22-38

Psychological Stress among Higher Secondary School Students during Covid Era in relation to Gender,

Caste, and Locality

Dr. Venkateswar Meher \& Laxmi Meher

Deb, S., Stordi, E., Sun, J. (2015). Academic stress, parental pressure, anxiety, and mental health among Indian high school students. International Journal of Psychology and Behavioral Sciences, 5(1), 26-34. DOI: 10.5923/j.ijpbs.20150501.04

Fromel, K., Safar, M., Jakubec, L., Groffik, D. \& Zatka, R. (2020). Academic stress and physical activity in adolescents. BioMed Research International. DOI: 10.1155/2020/4696592

Jain, H. (2017). A study of psychological capital as moderator of reactions to stress. Retrieved from- http://hdl.handle.net/10603/194245

Jose, T. T., Nikitha, S. \& Valsaraj, B. P. (2014). A correlational study on academic stress and self-esteem among higher secondary students in selected schools of Udupi District. 4(1). Retrieved from- www.researchgate.net

Kaur, M. (2011). Academic achievement and personality of adolescents in relation to academic, emotional, and social stress. Retrieved from- http://hdl.handle.net/10603/84858

Lazarus, R. S \& Folkman, S. (1984). Stress, appraisal, and coping. New York: Springer in Stangor, C. \& Walinga, J. (2014). Introduction to Psychology (1st Ed.). B. C.: BC campus. Retrieved from http://opentextbc.ca/introductionpsychology/

Lazarus, R. S. (1991). Emotion and adaptation. New York: Oxford University Press. in Krohne, H. W. (2001). Stress and coping theories. The International Encyclopedia of the Social \& Behavioral Sciences, 22, pp. 15163-15170. DOI: 10.1016/B0-08-043076-7/03817-1

Martin, M., Cayanus, J. L., Weber, K., Goodboy, A. K. (2006). College students' stress and its impact on their instructors. Retrieved fromhttps://www.researchgate.net/publication/209835825

Nayak, R. (1996). A developmental study of stress and coping. Retrieved fromhttp://hdl.handle.net/10603/188631

Pascoe, M. C., Hetrick, S. E. \& Parker A. G. (2019). The impact of stress on students in secondary school and higher education. International Journal of Adolescence and Youth, 25(1), 104112.

Raghavan, S. (2013). A Study on accelerating the academic performance of adolescent students through intervention for reducing examination stress and anxiety. Retrieved fromhttp://hdl.handle.net/10603/265198

Rana, A., Gulati, R. \& Wadhwa, V. (2019). Stress among students: An emerging issue. Integrated Journal of Social Science, 6 (2), 44-48.

Rao, A. S. (2020). Academic stress and adolescent distress: the experience of 12th standard students in Chennai, India. Unpublished thesis. The University of Arizona, University Libraries. Retrieved from http://hdl.handle.net/10150/194424

Reddy, K. J., Menon, K. \& Thattil, A. (2017). Understanding academic stress among adolescents. Artha-Journal of Social Sciences, 16(1), 39-52.

Sagar, P. \& Singh, B. (2017). A study of academic stress among higher secondary school students. International Journal of Creative Research Thoughts (IJCRT), 5(4).

Sandhu, H. (2014). A study of sleep-related disturbances among adolescents in relation to academic achievement anxiety stress coping and familial factors. Retrieved fromhttp://hdl.handle.net/10603/83108

Selye, H. (1956). The stress of life. New York: McGraw Hill

Strangor, C. \& Walinga, J. (2014). Introduction to psychology (1st Ed.). B.C: BC campus. Retrieved from http://opentextbc.ca/introductionpsychology/

Suldo, M. S., Shaunessy, E., Thalji, A., Michalowski, J \& Shaffer, E. (2009). Sources of stress for students in high school college preparatory and general education programs: Group differences and associations with adjustment. Adolescence, 44(176), Libra Publishers, San Diego. 
International Journal of Theory and Application in Elementary and Secondary School Education (IJTAESE), Vol. 3 (2), 22-38 Psychological Stress among Higher Secondary School Students during Covid Era in relation to Gender, Caste, and Locality

Dr. Venkateswar Meher \& Laxmi Meher

Tuncay, N., Müdüroğlu, R. \& Bulut, A. (2020). Educational stress, social stress, and gender differences among university students. Journal of Educational and Instructional Studies in the World, 10 (2), 37-46.

Yikealo, D., Tareke, W. and Karvinen, I. (2018). The level of stress among college students: A case in the college of education, Eritrea Institute of Technology. Open Science Journal, 3 (4). DOI: 10.23954/osj.v3i4.1691. 